\title{
UNRESOLVED QUESTIONS FOR THE CONTROLLED GROUP OF CORPORATIONS
}

\author{
PHILIP C. CooK*
}

I. INTRODUCTION.................................., 540

II. Characteristics of a Controlled Group of Corporations ................................ 542

III. Legal Framework Governing Plans of Controlled EMPLOYERS PRIOR TO ERISA.......................... 543

A. Pre-ERISA Law.............................. 543

B. Legislative History and Purpose of Section 414(b) .... 546

IV. Coverage and Discrimination IN THE Controlled Group ....................................... 549

A. Prerequisites to Qualification ...................... 549

1. The Percentage Coverage Test ................. 549

2. The Nondiscriminatory Classification Test ........ 550

B. Unresolved Issues in the Coverage of Controlled Group Plans.......................................... 552

1. Use of Section 414(b) to Qualify a Plan Not Qualifying Under Prior Law ......................... 552

2. Designation of Multiple Plans in a Controlled Group

3. Effect of Age and Service Exclusions on Nondiscriminatory Classification Determinations............. 558

4. Comparability in the Controlled Group ........... 561

V. Single Plan Versus Separate Plans for Controlled GROUP of EMPLOYERS............................... 562

A. Definition of a Single Plan ...................... 562

B. Consequences of a Single Plan ................... 563

1. Unified Reporting .......................... 564

* B.S. 1968, Georgia Institute of Technology; J.D. 1971, Harvard University; Partner ì Atlanta and Washington, D.C. law firm of Alston, Miller \& Gaines.

THE FOLLOWING CITATION WILL BE USED IN THIS ARTICLE:

Employee Retirement Income Security Act of 1974, Pub. L. No. 93-406, 88 Stat. 829 (codified in scattered sections of $5,18,29,31,42$ U.S.C.) [hereinafter cited by session law sections of ER1SA].

All references to and quotations of Treasury Regulations are to the current version as amended. Citations indicate the year of original adoption. 
2. Asset Allocations .......................... 564

3. Cost Determinations ........................ 564

4. Tax Deduction Rules ........................ 564

5. Plan Terminations ........................ 565

6. Transfer of Employees Between Corporations ...... 566

C. Merger of Separate Plans into a Single Plan ......... 566

D. Uncertainties Associated with Maintenance of Single

Plans in the Controlled Group ..................... 568

1. Profit Sharing Plans: Allocation of Contributions and Forfeitures ................................ 568

2. Defined Benefit Plans: Uncertainties in Allocation of Cost .................................... 572

VI. Conclusion .............................. 574

\section{INTRODUCTION}

Section 414(b) of the Internal Revenue Code, which was added by ERISA, provides in part:

For purposes of sections 401, 410, 411, and 415, all employees of all corporations which are members of a controlled group of corporations (within the meaning of section 1563(a), determined without regard to section 1563(a)(4) and (e)(3)(C)) shall be treated as employed by a single employer. ${ }^{1}$

No other provision of ERISA has imposed a more fundamental change upon the legal framework governing the mamtenance of qualified plans $^{2}$ in the private sector. ${ }^{3}$ Yet the fourth anniversary of ERISA has passcd without a significant effort by the Internal Revenue Service to address effectively many of the policy choices presented by section 414(b).

The principal purpose for enacting section 414(b) was to expand the application of the qualified plan coverage and nondiscrimination standards of the Code froin simgle corporate entities ${ }^{4}$ to controlled

1. I.R.C. $\$ 414$ (b). Section 414(b) was added to the Code by ERISA \& 1015.

2. If a pension or profit sharing plan is "qualified" under I.R.C. $\S 401$, then the plan is exempt from taxation, I.R.C. $\$ 501$, and the employer's contributions to the plan are currently deductible, subject to the rules of I.R.C. \$ 404(a).

3. Section 4(b)(1) of ERISA exempts governmental plans from the Act's coverage. Section 3(32) of ERISA defines a "governmental plan" as:

A plan established or maimtaimed for its employees by the Government of the United States .... The term "governmental plan" also includes any plan to which the Railroad Retirement Act of 1935 or 1937 applies, and which is financed by contributions required under that Act and any plan of an international organization which is exempt from taxation under the provisions of the International Organizations Immunities Act (59 Stat. 669).

4. Prior to enactment of ERISA, the requirements for qualification were apphicable separately to each corporate entity that adopted a qualified plan without regard to its status as a 
groups $^{5}$ of corporations. ${ }^{6}$ At this writing, however, it is impossible, except in extreine situations, to advise a controlled group of corporations on the exact impact of section 414(b) upon coverage within the group. In practical terms, most qualified pension and profit sharing plans that were maintained by members of controlled groups, and were in existence at the time ERISA was enacted have been amended to comply with ERISA and approved by the Service without serious scrutimy of the coverage of the group. In addition, section 414 (b) is widely viewed as overruling regulations and rulings of the Service that required each corporate entity to satisfy imdependently the requirements of the Code and that placed constraints upon the ability of affiliated corporate entities to adopt a single qualified plan for their einployees. ${ }^{7}$ Yet, the extent to which these rules of prior law inay have continuing effect after ERISA remaims unclear.

To date, the published regulations under section 414 (b) have dealt principally with the definition of a controlled group. ${ }^{8}$ In addition, the rules for the crediting of service in the controlled group context have been set forth in substantial detail in regulations issued by the Department of Labor. ${ }^{9}$ The published rulings and regulations, however, deal only incidentally with the basic questions of coverage and discrimination in the controlled group. ${ }^{10}$ Thus, the precise impact of section

member of a controlled group. See Rev. Rul. 69-260, 1969-1 C.B. 116, and the text accompanying notes 21-32 infra. Consequently, one member of a controlled group could adopt a qualified plan for its employees even if other members of the group did not maintain a plan.

5. For a discussion of the definition of a controlled group of corporations, see text accompanying notes 11-20 infra.

6. Congress was also concerned with the use of sole proprietorships, partnerships and other non-corporate ownership forms to circumvent the coverage and antidiscrimination standards of the Code. Accordingly, section 414(c) was adopted, imposing upon commouly controlled "trades or busimesses" rules similar to those established under section $414(\mathrm{~b})$ for controlled groups of corporations.

7. See, e.g., Scharf, Establishing Multiple Employer Plans May Be Solution to Section 414 Problems of Controlled Employers, 3 J. Pension Plan \& Compliance 279 (1977).

8. See Proposed Treas. Reg. \& 1.414(b)-1, 5 Pens. Plan Guide (CCH) I 20138 (proposed Nov. 5, 1975). See also Treas. Reg. $\$ \S 1.414(c)-1$ to -5 (1965); 1.414(f)-1 (1978).

9. In general, these rules provide that all service with any member of the controlled group must be credited for purposes of eligibility and vesting. 29 C.F.R. $\$ \$ 2530.210$ (a), (d) (1978). For purposes of benefit accrual, only years of plan participation must be credited. 29 C.F.R. $\S 2530.210$ (a)(2) (1978). See generally Schollander, Control Group Service Computations, 3 J. PENSion Plan \& Compliance 271 (1977).

10. The principal regulation published to date dealing with the apphication of the coverage standards of the Code to controlled groups is Treas. Reg. $\& 1.410(\mathrm{~b})-1(\mathrm{~d})(8)(1977)$, whicll provides in its entirety:

(8) Certain controlled groups. In applying the percentage test and classification test described in paragraph (b)(1) and (2) of this sectiou for a year, all the employees of corporations or trades and businesses whose einployees are treated as employed by a single employer by reason of section 414 (b) or (c) must be taken into account. The preceding sentence shall apply for a plan year if, on 1 day in each quarter of such plan year, 
414(b) upon qualified plans for controlled groups of corporations is unknown. This Article will briefiy explain the definition of a controlled group of corporations, describe the legal status of controlled employer plans prior to ERISA, discuss the reasons why section 414(b) was enacted, discuss coverage and discrimination in controlled group plans, pinpoint the problems caused by section 414(b) and the choice between a single plan and separate plans for inembers of a controlled group, and finally, discuss several possible solutions to these problems.

\section{Characteristics of a Controlled Group of Corporations}

This Article will not undertake a detailed discussion of the definition of a controlled group of corporations-a topic that las recently been the subject of a lively debate in judicial forums ${ }^{11}$-yet some understanding of the cliaracteristics of a controlled group is essential to the following discussion. The concept of a "controlled group of corporations" originated in the Revenue Act of $1964^{12}$ as a inechanisin for limiting the ability of related economic interests to utilize inultiple-corporate entities for artificial tax advantage. ${ }^{13}$ The principal concern was the circuinvention of the corporate tax surcharge rates by the use of multiple corporations. ${ }^{14}$ Section $1563\left(\right.$ a) ${ }^{15}$ defines a controlled group of corporations as two or more corporations that are component menibers of a "parent-subsidiary" controlled group, a "brother-sister" controlled group or a "combined" controlled group. ${ }^{16}$ Generally, a parent-subsidiary controlled group consists of one or nore chains of corporations connected through eighty percent stock ownership with a common parent corporation. ${ }^{17} \mathrm{~A}$ brother-sister controlled group, on the other hand, consists of two or nore corporations that are owned by common groups of five or fewer persons in certain prescribed percentages. ${ }^{18} \mathrm{~A}$ com-

such corporations are members of a controlled group of corporations (within the meaning of section $414(\mathrm{~b})$ ) of such trades or businesses are under common control (within the meaning of section $414(\mathrm{c})$ ).

11. See Fairfax Auto Parts v. Commissioner, 548 F.2d 501 (4th Cir.), rev'g 68 T.C. 620 (1977). See also Charles Baloian Co., 68 T.C. 620 (1977); T.L. Hunt, Inc., 35 T.C.M. (CCH) 966 (1976), rev'd, 562 F.2d 532 (8th Cir. 1977). 1963).

12. Pub. L. No. $88-272, \S 235,78$ Stat. 19 (adding 1.R.C. $\S 1563$ for taxable years ending after

13. See note 36 infra and accompanying text.

14. See note 36 infra and accompanying text.

15. I.R.C. $\S 1563(\mathrm{a})$.

16. Id,

17. Id. $\S 1563(\mathrm{a})(1)$.

18. Id. \$1563(a)(2). In general, two or more corporations will constitute a brother-sister controlled group where both of the following tests are met: (1) five or fewer persons own at least eighty percent of the total combimed voting power or at least eighty percent of the value of all classes of stock of each corporation; and (2) the same five or fewer persons own more than fifty 
bined controlled group, as its name implies, consists of three or more corporations comprised of a combination of brother-sister and parentsubsidiary groups. ${ }^{19}$

Thus, a controlled group's composition and degree of affiliation can vary markedly. For example, the controlled group definition could encompass a publicly traded New York Stock Exchange company whose business might be conducted through a wholly owned subsidiary rather than through a division. On the other hand, the definition also could cover two closely held brother-sister corporations whose sole relationship was fifty-one percent common ownership by a group of common stockholders, even when the common stockholders are wholly divorced froin active inanagement of both compamies. ${ }^{20}$

\section{Legal Framework Governing Plans of Controlled EMPLOYERS PRIOR TO ERISA}

\section{A. Pre-ERISA Law.}

Prior to the enactinent of ERISA, two or more corporationswhether or not they were affiliated-could jointly sponsor a qualified employee benefit plan. The principal benefit of joint sponsorship was enhanced investment capacity through the commingling of the respective contributions. However, numerous rules ignoring the unity of a joint plan limited the attractiveness of sucli plans. For instance, each einployer had to ineet the qualification requirements independently. ${ }^{21}$ Thus, if a parent and a subsidiary corporation (or a brother and a sister) corporation jointly adopted a pension plan for their respective employees, the IRS would require eacl corporation to satisfy independently the coverage and the nondiscrimination requirements with respect to its own einployees, ${ }^{22}$ to determine separately the cost for

percent of the total combined voting power of all classes of stock entitled to vote or more than fifty percent of the total value of all classes of stock of each corporation, taking into account only the sinallest percentage of stock ownership of each person in any of the corporations. See Treas. Reg. $\$ \S 1.1563-1$ to -4 (1965); Teinp. Treas. Reg. \$\$ 11.414(c)-1 to -4 (1975). See generally Bluestein \& Van de Ven, Handling Qualified Plans for Related Groups in View of Recent Court Decisions, $46 \mathrm{~J}$. TAX. 350 (1977).

19. I.R.C. $\$ 1563(\mathrm{a})(3)$.

20. Apart from Subchapter D of the Code, a parent-subsidiary controlled group may be subject to federal imcoine tax rules that are significantly different from those apphed to a brothersister controlled group. The parent-subsidiary group is normally ehigible to elect to file a consohdated federal incoine tax return while the brother-sister controlled group is not eligible to file a consolidated tax return. I.R.C. $\$ \$ 1501,1504$.

21. Rev. Rul. 69-250, 1969-1 C.B. 116; Treas. Reg. $\$ 1.401-1$ (d) (1960).

22. The best stateinent of the Service's view of sucl joint plans was that of Isidore Goodman the longtime Chief of the IRS Pension Trust Branch, who said:

A single plan and trust may be used by a group of einployers, regardless of their 
its own employees ${ }^{23}$ and to make separate contributions to fund the plan. ${ }^{24}$ Moreover, the Service required maintenance of separate records to reflect each contributing corporation's pro rata share of the trust fund and prohibited the use of one corporation's allocable portion of the assets to satisfy another corporation's plan liabilities. ${ }^{25}$ From a legal viewpoint the "joimt" adoption of a simgle plan by several affiliated corporate entities was somewhat illusory. It was more accurate to state that each employer adopted its own separate plan, but shared plan documents with the other adopting employers.

This emphasis on the separate status of each corporate entity's plan created technical barriers to the establishnient of joint, qualified plans by members of controlled groups of corporations. For example, in Revenue Ruling 69-525, ${ }^{26}$ the Service ruled that the actuarial cost of a qualified pension plan adopted by two affiliated employers could not be determined on an aggregate basis and apportioned between the adopting employers. Instead, cost had to be determined separately for each adopting employer unless the adopting employers were unable to determine cost separately. The ruling nullified economies of scale po-

degree of affiliation, but each employer separately must satisfy the requirements for qualification and deductions. In other words, it is necessary to establish that the applicable requirements are met by each employer as if he adopted and maintained the plan exclusivcly.

Isidore Goodman on Qualified Pension and Profi-Sharing Plans Under the Internal Revenue CodeSpeeches delivered between October 20, 1955 and November 21, 1966, Pens. Profit Sharing ReP. If 19,012.1 (Nov. 9, 1960).

23. Rev. Rul. 69-525, 1969-2 C.B. 102. See also Rev. Rul. 70-532, 1970-2 C.B. 95.

24. Rev. Rul. 71-96, 1971-1 C.B. 132. In that ruling, a parent corporation was not permitted to deduct a contribution made on behalf of its subsidiary. For a limited exception to this rule, see note 28 infra.

25. The use of plan assets of one controlled employer to satisfy the plan liabilities of another affiliated employer violates the exclusive benefit rationale of Revenue Ruling 69-570, 1969-2 C.B. 91. See note 29 infra and accompanying text. Prior to ERISA many IRS examiners at the district level required an express statement that plan assets would not be so used in the case of commingled investment trusts maimtained in conjunction with multiple plans for affiliated employers. See also Rev. Rul. 73-534, 1973-2 C.B. 132; Rev. Rul. 69-502, 1969-2 C.B. 89.

26. 1969-2 C.B. 102. The ruling illustrates three pre-ERISA situations involving defined benefit pension plans of multiple employers. In the first situation, the general rule is established that where "[e]ach corporation is able to determine the separate cost" of its plan, a separate cost determination must be made for each plan. Id. at 103. In the sccond situation, it is noted that "[s]ince employees are continually shifted between the two corporations [which sponsor the plan], it is not feasible to determine by separate computations the costs properly attributable to eacl corporation." Id. Accordingly, in the second situation the ruling sanctions determination of actuarial cost on an aggregate basis and apportionment of cost between the two corporations on the basis of the relative size of the participating payrolls.

The ruling has had significant nuisance value in the case of plans maintained by a large number of affiliated employers. Normally the most efficient method for the plan actuary is to aggregate the data for all plans participants, make a single cost computation, and then apportion cost among all participating employers. The ruling implies that such a method is not permitted unless it is impossible to make a separate cost computation for each participating employer. 
tentially available in cost determinations for controlled groups and resulted in erratic cost allocations for small employers within the group. ${ }^{27}$ Similarly, in Revenue Ruling $69-35,{ }^{28}$ the Service ruled that in the case of a profit sharing plan maintamed jointly by a parent corporation and its wholly owned subsidiary, amounts contributed by one corporation would not be deductible by that corporation insofar as they were allocated to the accounts of participants employed by the other corporation.

The most extreme example of the technical barriers is Revenue Ruling $69-570,{ }^{29}$ which dealt with a profit sharing plan adopted by a parent corporation and its four subsidiaries. The plan failed to qualify because it provided that a forfeiture occurring by reason of an einployee's termination of exployment would be reallocated among par-

27. A general discussion of the methods of computation of actuarial cost for a defined benefit pension plan is beyond the scope of this Article. The actuarial liability of any plan is a function, inter alia, of the benefits provided, the age and compensation levels of employees, and the actuarial assumptions with respect to interest rates, mortality, and turnover. In addition, plan "costs" may vary widely depending upon the actuarial "method" used to combime these factors. Where several corporate entities sponsor one plan, the most efficient manner of determining cost, regardless of the actuarial method being used, will be to aggregate all employee data and determine a single cost for the entire pool of employees. The cost so determined is then apportioned among the participating entities by various methods. For example, cost might be apportioned in proportion to the participating payrolls. Where the Service insists that a separate cost computation be made for each entity based on the employee data of that entity, the work of the actuary is multiplied. In addition, the pooling of data for a single cost computation may also serve an averaging function. For example, if a small entity has a disproportionate number of older employees, the separate computation of that entity's cost might produce a higher liability than would lave been the case if cost lad been computed on an aggregate basis for all entities and prorated among them.

28. 1969-1 C.B. 117. The general rule announced in Revenue Ruling 69-35 is, of course, subject to an express statutory exception recognized in the ruling. Section 404(a)(3)(B) permits a deduction for special "make-up contributions" in certain circumstances. In general, section 404(a)(3)(B) is applicable where one member of an affiliated group within the meaning of section 1504 (as contrasted to a controlled group within the meaning of section 1563(a)) is prevented from making a contribution to its profit sharing plan because it has no current or accumulated earnings or profits. In such a situation, the other members of the affiliated group may make a contribution on belialf of the financially disabled corporation's plan and deduct it.

The scope of section 404(a)(3)(B) is extremely limited, simce it is only applicable where there is a complete absence of current or aceumulated earnings and profits as contrasted to a mere financial inability on the part of the poor corporation to make a contribution to the plan. In addition, it is the position of the Service that section 404(a)(3)(B) is applicable only where the contribution of the poor corporation is required under a formula set forth in the plan. See Treas. Reg. $\$ 1.404(a)-10(a)(2)$ (1956). Thus, section 404(a)(3)(B) is applicable regardless of whether a consolidated return election is actually made.

29. 1969-2 C.B. 91 . In Revenue Ruling 71-148, 1971-1 C.B. 117, the Service retreated somewhat in a situation involving a profit slaring plan maintained by a corporation and ten subsidiaries where "[d]ue to the varying manpower needs of the corporations, employees are moved about from one corporation to another, . . . usually on a daily basis." Id. Since the origin of forfeited amounts was "unascertainable," the ruling holds that Revenue Ruling 69-570, 1969-2 C.B. 91, was not applicable and that forfeitures could be reallocated under any reasonable method. 
ticipants employed by all of the corporations in the controlled group, rather than solely aunong the participants employed by the corporation that employed the terminated employee. The stated rationale of Revenue Ruling 69-570 was the Service's interpretation of the "exclusive benefit" requirement of the Code. Section 401(a)(2), as in effect both before and after enactment of ER1SA, provides that a plan will not qualify unless

under the trust instrument it is impossible, at any time prior to the satisfaction of all liabilities with respect to employees, ... for any part of the corpus or income to be . . . used for, or diverted to, purposes other than for the exclusive benefit of [an employer's] employees or their beneficiaries. ${ }^{30}$

From this general admonition, apparently intended to prevent an einployer from recapturing funds previously contributed to a plan, the Service reached the somewhat surprising conclusion that a plan permitting contributions by one einployer to benefit employees of another affiliated employer violated the exclusive benefit requirement.

These three revenue rulings seen to be based on other unarticulated reasons. Where the operation of a qualified plan permits the use of one einployer's contributions for the benefit of an affiliated corporation's employees, the Service might well be concerned not only with the impact on the qualified plan, but also with the tax consequences of this transfer of a benefit from one corporation to the other. If a parentsubsidiary controlled group filed a consolidated return, the systematic discharge by one corporation of the pension obligations of another meinber would subvert the elaborate rules set forth in the consolidated return regulation, which seek to properly apportion income and basis within the consolidated group. ${ }^{31}$ Moreover, under traditional tax analysis, the systeinatic discharge by a brother corporation of the pension obligations of a sister corporation might be viewed as a constructive dividend to the common shareliolder followed by a correlative contribution to the capital of the sister corporation. ${ }^{32}$

\section{B. Legislative History and Purpose of Section 414(b).}

The Service's interpretation of the exclusive benefit rule restricted the usefulness of joint plans for controlled groups of corporations. Despite the resulting technical difficulties, Congress did not design section

30. I.R.C. $\S 401(a)(2)$.

31. See Treas. Reg. $\$ 1.502-11$ (1973).

32. See, e.g., David Aylsworth, 32 T.C.M. (P-H) II 63,221 (1963); George W. Offutt III, 32 T.C.M. (P-H) I 63,126 (1963), affd, 336 F.2d 483 (4th Cir. 1964); Foreum-James Co. v. Commissioner, 7 T.C. 1155 (1946), appeal dismissed, 176 F.2d 311 (6th Cir. 1949); Rev. Rul. 69-630, 1969-2 C.B. 112 . 
414(b) to alleviate them. Rather, Congress sought to deal with a more fundamental problem. Some employers had adopted multiple-corporate forms im order to circumvent the coverage and the antidiscrimination requirements of section 401 . For instance, a busmess umit could split itself into two corporations; one employmg highly compensated persons, the other employmg rank-and-file workers. The former would adopt a pension plan, the latter would not. The result-that the business' executives had a pension plan but that its workers did not-would not prevent the plan from beimg qualified, despite the transparent subversion of the antidiscrimination provisions. ${ }^{33}$

Consequently, the House Committee reported out section 414(b), stating the purpose as follows:

The committee, by this provision [Section 414(b)], intends to make it clear that the coverage and antidiscrimination provisions cannot be avoided by operating through separate corporations instead of separate branches of one corporation. For example, if managerial functions were performed through one corporation employing highly compensated personnel, which has a generous pension plan, and assembly-line functions were performed through one or more other corporations employing lower-paid employees, which have less generous plans or no plans at all, this would generally constitute an impermissible discrimination. By this provision the committee is clarifymg this matter for the future. $1 \mathrm{t}$ intends that prior law on this point be determined as if this provision had not been enacted. ${ }^{34}$

At the same time, the Committee stressed that the new section would not require complete uniformity in the qualified plans throughout the controlled group.

[T] he Committee provision is not intended to mean that all pension plans of a controlled group of corporations $* * *$ must be exactly alike, or that a controlled group could not have pension plans for some corporations but not for others. Thus, where the corporation in question contains a fair cross-section of high- and low-paid employees (compared to the employees of the controlled group as a whole), and where the plan coverage is nondiscriminatory with respect to the einployees of the corporation in question, it is anticipated that the Internal Revenue Service would find that the plan met the antidiscrimination tests, even though other corporations in the controlled group had a less favorable retirement plan, or no plan at all. On the other hand, if, looking at the controlled group as a whole, it were found that a disproportionate number of highly compensated employees were covered under the plan of the corporation in question, or that the average compensation of covered employees was substantially higher in that plan than the average compensation of noncov-

33. The most flagrant example under prior law was Packard v. Commissioner, 63 T.C. 621 (1975). But see Burnetta v. Commissioner, 68 T.C. 387 (1977).

34. H.R. REP. No. 93-807, 93d Cong., 2d Sess. 50 (1974). 
ered employees, it would be anticipated that the plan would not be found to be qualified, because the corporation does not contain a fair cross section of the controlled group of employees. ${ }^{35}$

Section 414 (b) can be seen as a logical application of the reasoning that led to the creation of the concept of a "controlled group of corporations." The surcliarge form of corporate taxation was designed to limit the corporate tax liability of small businesses and thus to encourage them to adopt corporate form. Yet "mediun and large enter prises have in soine cases taken advantage of the lower rates afforded small business by organizing their corporate structure in multiple corporate form."36 Similarly, section 414(a) was created to prevent business organizations from masquerading as several in order to sidestep nondiscrimination provisions otherwise applicable to them. Since, by definition, the legal differences among meinbers of a controlled group are artificial ones, the einployees of the several meinbers are to be treated as if they were the employees of one employer.

Thus, even though the legislative history of section 414 (b) indicates that Congress was not focusing on the elaborate rules constructed by the IRS prior to the enactment of ERISA, ${ }^{37}$ the conceptual approacl of those rules-einphasizing the separateness of the inembers of the controlled group and requiring de facto independence of their respective plans-is irreconcilable with both the language and the conceptual approacl of section 414(b). For instance, the "exclusive benefit" rule of Revenue Ruling $69-570^{38}$ for qualification of plans simply cannot be squared with the literal terms of section 414(b): "all employees of all corporations which are members of a controlled group of corporations . . . shall be treated as employed by a single employer."39

35. Id. $50-51$.

36. H.R. ReP. No. 749, 88th Cong., Ist Sess. 107 (1963), reprinted in 1964-1 (Part 2) C.B. 125, $240-41$.

37. See text accompanying notes 26-30 supra.

38. 1969-2 C.B. 91 .

39. I.R.C. § 414(b) (emphasis added). Section 413(c) of the Code, also added by ERISA, expressly provides that the narrow construction of the exclusive benefit requirement is overruled with respect to "a plan maintained by more than one employer." 1.R.C. $\$ 413$ (c). Section 413(c)(2) provides:

(2) Exclusive benefit. For purposes of section 401(a) in determining whether the plan of an einployer is for the exclusive benefit of his employees and their beneficiaries all plan participants shall be considered to be his employees.

The provisions of section 413 (c) could be viewed as applying to a plan adopted by one or more employers of a controlled group. If two or more corporations that are members of a controlled group adopt the same plan, section 413(c) seems applicable by its literal terms. If section 413 (c) is applicable to a plan adopted by two or more members of a controlled group, then section 413(c)(2) would have the effect of expressly overruling the Service's exclusive benefit rationale in the context of the controlled group. Necessarily, Revenue Ruling 69-570 would have no continuing vahidity after ERISA. 
And how can the rules requiring separate maintenance of plans be reconciled with section 414(b) when the fullest effectuation of the underlying policies of the section occurs only when every employee of every corporation in the controlled group is covered by the same einployee benefit plan? The balance of this Article will consider the coverage standards that have developed for the controlled group in light of the basic policy of section 414(b) and the extent to which the controlled group of employers is free from the constramts of prior law in establishing a single plan for employees.

\section{Coverage and Discrimination IN THE Controlled Group}

\section{A. Prerequisites to Qualification.}

"Qualification" of an employee benefit plan creates substantial tax benefits that make qualified plans a desirable form of compensation. To qualify, a plan must meet the "coverage" tests, which are designed "to insure that stock bonus, pension or profit-sharing plans are operated for the welfare of einployees in general, and to prevent the trust device from being used for the benefit of shareholders, officials, or highly paid einployees . . ."40 The Code provides several alternative inethods of meeting the coverage requireinents.

\section{The Percentage Coverage Test. Section 410(b)(1)(A) sets forth}

However, the IRS has taken the position in proposed regulations adopted under section 413(c) that section 413(c) is not applicable to a plan sponsored by multiple employers if all of the sponsors are members of the same controlled group. See Proposed Treas. Reg. § 1.413-2, 43 Fed. Reg. 38602, 38604 (1978). The proposed regulations define a multiple-employer plan as a "single plan" maintained by "more than one employer." Proposed Treas. Reg. § 1.413-2(a)(2). However, for purposes of this test "the number of employers maintaining the plan is determined by treating any employers described in section 414(b) (relating to a controlled group of corporations) . . . as if sucl employers are a single employer." Id. Under this interpretation, section 413(c) would not be applicable to a plan sponsored by a controlled group of employers unless there was also at least one non-group member sponsoring the plan.

The position adopted in the proposed regulations is questionable as a matter of statutory interpretation. Section 414(b) provides that "[f]or purposes of sections 401, 410, 411 and 415, all einployees of all corporations which are members of a controlled group of corporations . . . shall be treated as employed by a single employer." I.R.C. \$ 414(b). Thus, section 414(b) expressly does not include any cross reference to section 413 . On the other hand, section 413 is hiterally applicable "[i]n the case of a plan maintained by more than one employer." L.R.C. $\$ 413(\mathrm{c})$. Accordingly, it would appear that unless section $414($ b) is applicable for purposes of section 413 , which it is not, the Service's position cannot be sustained. Moreover, the provisions of section 414 (b) and 413(c) are neither contradictory nor inutually exclusive.

The point may be moot since section 414(b) may be interpreted to impose eacl of the requireinents of section 413 (c) on plans maintained by controlled employers. However, the Service's position with respect to 414 (b) has not yet been fully developed.

40. H.R. REP. No. 2333, 77th Cong., 2d Sess. 103 (1942) (empliasis added), reprinted in 1942 2 C.B. $372,450$. 
a mathematical test of adequate coverage. Satisfaction of this test requires that a plan cover either at least seventy percent of all employees or at least eighty percent of all ehgible employees as long as seventy percent or more of all employees are ehgible. ${ }^{41}$ For the purposes of this test, the employer may exclude employees who have not met the minimum age and service requirements of the plan (which generally may not be greater than the later of age twenty-five and one year of service), nonresident aliens whose compensation is not from sources within the United States, and employees who are members of a unit of employees covered by a collective bargaining agreement if there is evidence that retirement benefits were the subject of good faith bargaining between the eniployer and the employee representatives. ${ }^{42}$

Section 414(b) provides that all employees employed by every niember of the controlled group must be considered im determining whether any simgle plan of any controlled group employer meets the percentage test. ${ }^{43}$ For many controlled groups, satisfaction of the percentage test will be difficult. If the controlled group consists of several eniployers of relatively equal size, each of which sponsors a separate plan, no employer in the group will meet the percentage test even though every employee of the group is covered by a comparable plan.

2. The Nondiscriminatory Classification Test. If a plan cannot ineet the percentage coverage test, there are two other methods of satisfying the coverage requirements. First, section $410(\mathrm{~b})(1)(B)$ provides that a plan not nieeting the percentage requirement will nonetheless qualify if the plan covers a "fair cross section" of the employees. ${ }^{44} \mathrm{~A}$ fair cross section is defined to mean "a classification set up by the employer and found by the secretary not to be discriminatory in favor of employees who are officers, shareholders, or highly compensated."45

The question of whether a classification established by an employer discriminates in favor of officers, shareholders or highly compensated employees is, of course, a question about which employers and the Service might reasonably disagree. Most of the development of the law concerning what constitutes a nondiscriminatory classification or a "fair cross section" occurred prior to enactment of ERISA. The

41. I.R.C. $\& 410(\mathrm{~b})(\mathrm{I})(\mathrm{A})$.

42. I.R.C. $\$ \S 410(\mathrm{~b})(1)(\mathrm{A}),(2)(\mathrm{A}),(2)(\mathrm{C})$.

43. Treas. Reg. $\$ \S 1.410(b)-(1)(d)(8)$ (1977). For example, if the controlled group consists of four corporations each having an identical number of employees and each maintaining a separate plan for its respective employees, no individual plan will cover more than $25 \%$ of the employees of the group. Accordingly, no individual plan will meet the $80 \%$ test.

44. I.R.C. \& 410(b)(1)(B).

45. Id. 
context in which the question arose concerned whether plans within a single corporation covering only salaried employees covered a fair cross section of all einployees. ${ }^{46}$ The principles that have developed in this area will generally be applicable in determining whether a plan covering the employees of one corporation covers a fair cross section of the einployees of the entire controlled group for purposes of section 414(b). ${ }^{47}$

In Revenue Ruling 70-200, ${ }^{48}$ the nost significant Revenue Ruling illustrating the concept of a "fair cross section," the Service held that a profit sharing plan limited to full-time salaried employees covered a fair cross section of all employees. The salaried and hourly einployees fell into the following coinpensation ranges:

\begin{tabular}{|c|c|c|c|c|}
\hline $\begin{array}{l}\text { Compensation } \\
\text { Range }\end{array}$ & $\begin{array}{c}\text { Total } \\
\text { Employees }\end{array}$ & $\begin{array}{l}\text { Excluded } \\
\text { Hourly } \\
\text { Employees }\end{array}$ & $\begin{array}{c}\text { Salaried } \\
\text { Participants }\end{array}$ & $\begin{array}{c}\text { Participants Who } \\
\text { Are Officers, } \\
\text { Shareholders } \\
\text { or Supervisors }\end{array}$ \\
\hline$\$ 25,000$ to $\$ 30,000$ & 4 & 0 & 4 & 4 \\
\hline$\$ 20,001$ to $\$ 25,000$ & 0 & 0 & 0 & 0 \\
\hline$\$ 15,001$ to $\$ 20,000$ & 25 & 18 & 7 & 7 \\
\hline$\$ 12,501$ to $\$ 15,000$ & 45 & 37 & 8 & 3 \\
\hline$\$ 10,001$ to $\$ 12,500$ & 50 & 38 & 12 & 3 \\
\hline$\$ 7,501$ to $\$ 10,000$ & 14 & 11 & 3 & 0 \\
\hline$\$ 5,001$ to $\$ 7,500$ & 9 & 4 & 5 & 0 \\
\hline$\$ 2,500$ to $\$ 5,000$ & 3 & 2 & 1 & 0 \\
\hline Total & 150 & 110 & 40 & 22 \\
\hline
\end{tabular}

In reviewing this coverage, the Service noted that twenty-two of the forty plan participants were officers, shareholders or supervisors. However, the coinpensation of all but four of the forty participants was substantially the saine as that of the excluded hourly einployees. Furthermore, the Service noted that the plan covered employees in all coinpensation ranges and that the coverage of medium- and low-paid einployees was inore than nominal. The Service concluded that the plan covered a fair cross section and therefore ruled that the plan cov-

46. See Commissioner v. Pepsi-Cola Niagra Bottling Corp., 399 F.2d 390 (2d Cir. 1968), rev'g 48 T.C. 75 (1958); Ed \& Jim Fleitz, Inc. v. Commissioner, 50 T.C. 384 (1968); Ray Cleaners, Inc. v. Commissioner, 27 T.C.M. (CCH) 23 (1968). See generally Goodman, When Will a Salaried-Only Plan Be Approved by the IRS, 9 TAX. FOR ACCOUNTANTS 170 (1972); Lurie, Coping with IRS: Tough Tests for Salaried-Only Plans in the Post-Pepsi Period, 32 J. TAX. 24 (1970); Lurie, Discrimination in Salaried-Only Plans: Defining the Outer Limits, 31 J. TAX. 322 (1969).

47. ERISA did not alter the relevant statutory test. Compare present I.R.C. $\$ 410(b)(1)(B)$ with pre-ERISA I.R.C. $\$ 401$ (a)(3)(B). Hence the revenue rulings and cases construing old I.R.C. $\S 401$ (a)(3)(B) cited in note 46 supra will have continuing vitality in construing the requirements of new I.R.C. $\$ 410(\mathrm{~b})(1)(\mathrm{B})$.

48. 1970-1 C.B. 101 . 
ered a nondiscriminatory classification. ${ }^{49}$

If the employer's plan fails to meet the percentage test or does not cover a "fair cross section" of employees, the plan's coverage may nonetheless satisfy the Code. The law has long permitted an employer sponsoring two or more separate plans that cover different groups of his employees to "designate" both plans as a single plan for purposes of satisfaction of the coverage and antidiscrimination tests. ${ }^{50}$ However, im order to designate the plans as a fictional single plan, the plans designated must be "comparable" in contributions or benefits. ${ }^{51}$ For two plans to be comparable, "the benefits provided for an employer's low paid employees, assuming a juxtaposition of two plans, must be at least as good as the benefits provided for the employer's higher paid supervisory employees." 52 The importance of the designation and comparability concepts have been enhanced by the passage of ERISA and section 414(b), since they diminish the likelihood that the plans of a controlled group will meet the percentage test.

The percentage test of coverage is a safe harbor rule. The fair cross section and the designation tests, on the other hand, are obscure and subjective. These tests can never be defined with complete precision due to their reliance on a factual determination of whether a fair cross section or comparability exists. This uncertainty is difficult to live with for any employer with an employee benefit plan. The uncertainty is more acute if the employer is a member of a controlled group of employers.

\section{B. Unresolved Issues in the Coverage of Controlled Groups Plans.}

1. Use of Section 414(b) to Qualify a Plan Not Qualifying Under Prior Law. One area of uncertainty is whether section 414(b) will operate to permit qualification of an employee benefit plan by reference to the employees of all the members of a controlled group when the plan would fail to qualify by reference only to the employees of the sponsor.

49. Id.

50. I.R.C. $\S 410(b)(1)$.

An einployer may designate two or unore plans as constituting a single plan which is intended to qualify for purposes of Section $410(b)(1)$ and this section, in which case all plans so designated shall be considered as a single plan in determining whether the requirements of such section are satisfied by each of the separate plans. A determination that the combinations of plans so designated does not satisfy such requirements does not preclude a determination that one or more of such plans, considered separately, satisfies such requireinents.

Treas. Reg. \& 1.410(b)-1(d)(3)(i) (1977).

51. Rev. Rul. 70-580, 1970-2 C.B. 91; Rev. Rul. 70-183, 1970-1 C.B. 104; Rev. Rul. 66-15, 1966-1 C.B. 83. See generally Metzer, Comparability Under Section 401(a): Of Theoretical or Practical Value?, 50 TAXES 459 (1972).

52. Metzer, supra note 51 , at 460 . 
The language of the Code justifies the conclusion that such qualification is permissible under ERISA, but the Service has yet to rule on the issue. This qualification approach can be illustrated by the following example, which is based on the facts of Revenue Ruling 70-200.53

Table A

\begin{tabular}{|c|c|c|c|}
\hline $\begin{array}{l}\text { Compensation } \\
\text { Range }\end{array}$ & $\begin{array}{c}\text { I } \\
\text { Corp. A } \\
\text { (Salaried } \\
\text { Employees) }\end{array}$ & $\begin{array}{c}\text { II } \\
\text { Corp. A } \\
\text { (Hourly Employees) }\end{array}$ & $\begin{array}{c}\text { III } \\
\text { Corp. B } \\
\text { (All Employees) } \\
\end{array}$ \\
\hline$\$ 25,000$ to $\$ 30,000$ & 4 & 0 & 0 \\
\hline$\$ 20,001$ to $\$ 25,000$ & 0 & 0 & 0 \\
\hline$\$ 15,001$ to $\$ 20,000$ & 0 & 18 & 7 \\
\hline$\$ 12,501$ to $\$ 15,000$ & 0 & 37 & 8 \\
\hline$\$ 10,001$ to $\$ 12,500$ & 0 & 38 & 12 \\
\hline$\$ 7,501$ to $\$ 10,000$ & 0 & 11 & 3 \\
\hline$\$ 5,001$ to $\$ 7,500$ & 0 & 4 & 5 \\
\hline$\$ 2,500$ to $\$ 5,000$ & 0 & 2 & 1 \\
\hline
\end{tabular}

Prior to the enactment of ERISA, if corporation A adopted a "salaried only" plan, the plan would fail to satisfy the coverage requirements because, considering only corporation $\mathrm{A}$, the plan would cover four highly compensated salaried employees but would not cover any of the lower-paid hourly employees. Under section 414(b), however, if corporation B maintains a "comparable" plan ${ }^{55}$ to the salaried-ouly plan of corporation $A$, then corporation $A$, im attemptimg to demonstrate the qualification of its plan, could "designate" its salaried-only plan plus the plan of corporation.B as a fictional single plan for purposes of ineetimg the coverage requirements. ${ }^{56}$ If such a designation were made, the fictional single plan would present the exact facts of Revenue Ruling 70-200. ${ }^{57}$ Since the Service held in that revenue ruling that the plan covered a fair cross section of the simgle sponsor's employees and since section 414(b) provides that all the employees within a controlled group shall be treated as employed by a simgle employer, corporation A's plan, considered im conjunction with corporation B's plan, should be considered a nondiscriminatory classification within the meaning of section $410(\mathrm{~b})(1)(B)$.

53. 1970-1 C.B. 101. See text accompanying notes $48-49$ supra.

54. Table A represents the employee coverage of three pension plans adopted by a controlled group of corporations. Column I of the table lists the salaried employees of corporation A by annual compensation. Column II sets forth in like manner the hourly employees of corporation $A$, and Column III tabulates all employees, salaried and hourly, of corporation B.

55. See text accompanying note 52 supra.

56. See Treas. Reg. \& 1.410(b)-1(d)(3)(i) (1977).

57. 1970-1 C.B. 101. See text accompanying notes 48-49 supra. 
Nonetheless, some IRS examiners have been unwilling to approve a salaried-only plan or other plan that would not have qualified under prior law. This reluctance appears to find some support in a reference in the committee reports to "plan coverage [that] is non-discriminatory with respect to the einployees of the corporation in question." 58 However, this reference is inapposite ${ }^{59}$ and the law seems quite clear on this poimt. The Service should therefore consider adding an affirmative statement in the regulations under section 414(b) clarifying the ability to qualify in this manner.

2. Designation of Multiple Plans in a Controlled Group. Another area of uncertainty is the extent to which the flexibility of "picking and choosing" within the controlled group will permit the contmued qualification of plans primarily covering highly compensated individuals notwithstanding the policies underlying section 414(b). Consider, for example, the controlled group of corporations reflected in Table B consisting of Rich Corporation A (column I), Rich Corporation B (column II), Cross Section Corporation (column III) and Poor Corporation (column IV) and employing persons falling into the following compensation ranges:

58. H.R. REP. No. 807, supra note 34. See text accompanying note 35 supra.

59. The phrase is imapposite to the situation in Table A because it is part of a sentence that illustrates the propositions that all qualified plans of a controlled group need not be exactly alike and that some members of a controlled group may have plans while others do not. The full sentence states:

Thus, where the corporation in question contains a fair cross section of high and low paid employees (compared to the employees of the controlled group as a whole), and where the plan coverage is non-discriminatory with respect to the employees of the corporation in question, it is anticipated that the Internal Revenue Service would find that the plan met the anti-discrimination tests even though other corporations in the controlled group had a less favorable retirement plan, or no plan at all.

H.R. REP. No. 807, supra note 34, at 52-53. The sentence does not require that a plan cover a fair cross section of both the corporation in question and the controlled group, which is, in essence, the interpretation necessary in order to argue that the phrase should prevent qualification of corporation A's Plan I. Rather, the sentence means that if the employees of one corporation are representative of all the employees in the controlled group and if the plan fairly covers the employees of the corporation, then the plan can qualify whcther or not other inembers of the group sponsor plans. If a plan covers a fair cross section of the relevant pool of employees, which under section 414 (b) is all the controlled group employees, the plan can quahify. There is no logical relationship between this statement and the argument that a controlled group plan must qualify by referring to a fraction of the relevant employee pool, those who happen to be employees of the sponsor. Moreover, the argument contimues the emphasis on the separateness of the members' plans despite the enactment of section 414(b), which discredits the rationale of that emphasis. See text accompanying notes 36-39 supra. 
Table B

\begin{tabular}{|c|c|c|c|c|}
\hline $\begin{array}{l}\text { Annual } \\
\text { Compensation }\end{array}$ & $\begin{array}{c}\text { Plan I } \\
\text { Rich } \\
\text { Corp. A }\end{array}$ & $\begin{array}{c}\text { Plan II } \\
\text { Rich } \\
\text { Corp. B }\end{array}$ & $\begin{array}{l}\text { Plan III } \\
\text { Cross Section } \\
\text { Corp. }\end{array}$ & $\begin{array}{c}\text { Plan IV } \\
\text { Poor } \\
\text { Corp. }\end{array}$ \\
\hline More than $\$ 25,000$ & 20 & 20 & 20 & 0 \\
\hline$\$ 20,001$ to $\$ 25,000$ & 20 & 20 & 20 & 0 \\
\hline$\$ 15,001$ to $\$ 20,000$ & 20 & 20 & 20 & 0 \\
\hline$\$ 12,501$ to $\$ 15,000$ & 0 & 0 & 20 & 40 \\
\hline$\$ 10,001$ to $\$ 12,500$ & 0 & 0 & 20 & 40 \\
\hline$\$ 7,501$ to $\$ 10,000$ & 0 & 0 & 20 & 40 \\
\hline \multirow[t]{2}{*}{$\$ 5,001$ to $\$ 7,500$} & $\underline{0}$ & $\underline{0}$ & 20 & 40 \\
\hline & 60 & 60 & 140 & 160 \\
\hline
\end{tabular}

Assume that prior to the enactment of ERISA, Rich Corporation A, Rich Corporation B, and Cross Section Corporation adopted separate, comparable pension plans covering all employees in each of the respective corporations. Assume further that no plan was adopted by Poor Corporation.

Prior to the enactment of ERISA, the plan of each corporation qualified separately under the percentage test. After enactment of ERISA, none of the plans qualify under the percentage test, simce employees of all corporations in the group must be considered. Thus, the issue in the post-ERISA period is whether the coverage of any of these plans-singly, or in combination-qualifies as a nondiscriminatory classification within the meaning of section $410(\mathrm{~b})(1)(B)$. For all three plans, the answer is unclear.

Certainly a strong argument can be made that Plan III covers a fair cross section of employees. As Table $\mathrm{C}$ below demonstrates, Plan III covers a distribution of employees (Table $\mathrm{C}$ column II) that is a fair cross section when compared to all employees (Table C column I).

\begin{tabular}{|c|c|c|c|c|}
\hline $\begin{array}{l}\text { Annual } \\
\text { Compensation }\end{array}$ & $\begin{array}{c}\text { I } \\
\text { All } \\
\text { Employees }\end{array}$ & $\begin{array}{c}\text { Table C } \\
\text { II } \\
\text { Covered by } \\
\text { Plan III }\end{array}$ & $\begin{array}{c}\text { III } \\
\text { Excluded } \\
\text { from Plan III }\end{array}$ & $\begin{array}{l}\text { IV } \\
\text { Excluded from } \\
\text { All Plans }\end{array}$ \\
\hline $\begin{array}{l}\text { More than } \$ 25,000 \\
\$ 20,001 \text { to } \$ 25,000 \\
\$ 15,001 \text { to } \$ 20,000 \\
\$ 12,501 \text { to } \$ 15,000 \\
\$ 10,001 \text { to } \$ 12,500 \\
\$ 7,501 \text { to } \$ 10,000 \\
\$ 5,001 \text { to } \$ 7,500\end{array}$ & $\begin{array}{l}60 \\
60 \\
60 \\
60 \\
60 \\
60 \\
60\end{array}$ & $\begin{array}{l}20 \\
20 \\
20 \\
20 \\
20 \\
20 \\
20\end{array}$ & $\begin{array}{l}40 \\
40 \\
40 \\
40 \\
40 \\
40 \\
40\end{array}$ & $\begin{array}{r}0 \\
0 \\
0 \\
40 \\
40 \\
40 \\
40\end{array}$ \\
\hline
\end{tabular}

The employees covered by Plan III also seem to qualify as a fair cross section when compared to the employees not covered by Plan III (Table C column III). On the other hand, the Service conceivably might 
argue that the relevant comparison is between the employees covered by Plan III (Table $\mathrm{C}$ column II) and the employees excluded from all plans (Table C column IV). When these two groups are compared, the plan probably fails to cover a fair cross section, since the compensation of the excluded employees is not "substantially the same"60 as the compensation of the covered employees.

The Committee reports squarely address the situation:

[W] here the corporation in question contains a fair cross-section of high- and low-paid employees (compared to the employees of the controlled group as a whole ) . . . it is anticipated that the Internal Revenue Service would find that the plan met the antidiscrimination tests, even though other corporations in the controlled group had . . . no plan at all. ${ }^{61}$

This statement clearly indicates that, at least with respeet to a single corporate entity in the group, the relevant comparison of the covered employees is with all employees in the group and not with the employees excluded from all plans. Thus, although the Service has not yet concurred with this analysis, if a plan covers the employees of one of the group's members, and if those employees represent a fair cross section of all the group's members, the plan should qualify.

Whether Plan I mamtamed by Rich Corporation A can qualify is more problematic. In seeking to establish the qualification of Plan I, Rich Corporation A would be free to designate Plan I and Plan III (of Cross Section Corporation) as constituting a simgle plan (referred to as "Plan I-III") for purposes of qualifying under section $410(b)(1) .{ }^{62}$ The following Table shows the results of this designation.

Rich Corporation $\mathrm{A}$, in establishing the qualification of designated Plan I-III, presumably would argue that the relevant comparison is between employees covered by Plan I-III (Table D column II) and em-

60. Rev. Rul. 70-200, 1970-1 C.B. 101.

61. H.R. REP. No. 807, supra note 34 , at 50 (emphasis added). For a discussion of this sentence, see note 59 supra.

62. Treas, Reg. $\$ 1.410$ (b)-1(d)(3) (1977). The regulation states that an employer may designate two or more plans as constituting a single plan. Id. $\$ 1.410(b)-1(d)(3)(i)(1977)$. By stating the designation option in permissive rather than mandatory terms, the Service does not require an einployer who wants to designate multiple plans as a simgle one to do so with reference to all of his plans. Thus, if an employer had three plans, one of which could qualify by itself and two of which could qualify only by designation together, the employer could designate the two without including the third. Since section 414 (b) treats all employees of a controlled group as having one employer, the separate einployers would appear to have similar flexibility in ehoosing which of the various members' plans to designate together in order to qualify. 


\begin{tabular}{|c|c|c|c|c|}
\hline \multirow[b]{2}{*}{$\begin{array}{l}\text { Annual } \\
\text { Compensation }\end{array}$} & \multicolumn{3}{|c|}{ Table D63 } & \multirow[b]{2}{*}{$\begin{array}{l}\text { IV } \\
\text { Excluded from } \\
\text { All Plans }\end{array}$} \\
\hline & $\begin{array}{c}\text { I } \\
\text { All } \\
\text { Employees }\end{array}$ & $\begin{array}{c}\text { II } \\
\text { Covered by } \\
\text { Plan I-III }\end{array}$ & $\begin{array}{c}\text { III } \\
\text { Excluded from } \\
\text { Plan I-III }\end{array}$ & \\
\hline More than $\$ 25,000$ & 60 & 40 & 20 & 0 \\
\hline$\$ 20,001$ to $\$ 25,000$ & 60 & 40 & 20 & 0 \\
\hline$\$ 15,00 \mathrm{I}$ to $\$ 20,000$ & 60 & 40 & 20 & 0 \\
\hline$\$ 12,501$ to $\$ 15,000$ & 60 & 20 & 40 & 40 \\
\hline$\$ 10,001$ to $\$ 12,500$ & 60 & 20 & 40 & 40 \\
\hline$\$ 7,501$ to $\$ 10,000$ & 60 & 20 & 40 & 40 \\
\hline$\$ 5,001$ to $\$ 7,500$ & 60 & 20 & 40 & 40 \\
\hline
\end{tabular}

ployees of the entire group (Table D column I). Alternatively, the corporation might argue that the pertinent comparison is between einployees covered by Plan I-III (Table D column II) and employees of the group not covered by Plan I-III (Table D column III). Either comparison arguably reflects a nondiscriminatory classification within the meaning of section 410 (b)(1) since, under the test articulated in Revenue Ruling 70-200, ${ }^{64}$ the compensation of the covered employees (column II) is substantially the same as that of the excluded employees (column III or column IV) and the plan covers those in the middle and lower brackets in inore than nominal numbers.

As previously indicated, the Service might argue that the relevant comparison is between the employees covered by Plan I-III (Table D column II) and those einployees not covered by any plan (Table D column IV). This comparison presumably would result in a failure to qualify. However, if the comparison is an incorrect one when plans are not designated for purposes of qualification, then the comparison is an incorrect one when plans are designated for purposes of qualification.

Finally, suppose that the management of Rich Corporation B also desires to qualify its Plan II by designating Plan II and Plan III (of Cross Section Corporation) as a simgle plan. This designation would produce coverage data identical to that set forth in Table D with reference to the Plan I-III designation. Common sense suggests that either Rich Corporation A or Rich Corporation B, but not both, may designate Cross Section Corporation's plan. However, the regulations fail to prohibit multiple use of a designee plan.

As a practical matter, Corporations A and B may have considerable freedom to inake these designations. The administrative process by

63. Column II of Table D is the sum of Column I and Column III of Table B.

64. 1970-1 C.B. 101. See text accompanying notes $48-49$ supra. 
which the IRS makes advance determinations with respect to the quahfied status of employee plans is still primarily oriented to the plans of single corporate entities rather than to controlled groups of corporations. ${ }^{65}$ If the plans maintained by the three corporations are separate plans, a separate application would be submitted for each plan. ${ }^{66}$ If the principal offices of the corporations are located in different IRS districts, each plan would be submitted to a different IRS office. ${ }^{67}$ While the basic forms by which qualified plans are submitted now require descriptive information concerning the qualified plans maimtamed by each corporation in the group, there is no prescribed format that gives examiners a good overview of the entire group's coverage. ${ }^{68}$ Instead, the employer who attempts to establish the qualification of his plan is given a great deal of latitude to present data placing the plan in its most favorable ight. ${ }^{69}$

In summary, the hypothetical controlled group faces much uncertainty. It is possible that none, one, two, or conceivably even all three of the plans continue to qualify after the enactment of ERISA, and there is no published authority that even suggests a definitive answer.

3. Effect of Age and Service Exclusions on Nondiscriminatory Classification Determinations. The preceding discussion was smiplified by the assumption that all of the employees of each of the three corporations were covered by the respective plan of each corporation. In reality, of course, plans normally have minimum age and service conditions that would exclude some employees of the corporation adopting the plan.

Prior to ERISA, the Code perumtted an initial eligibility period of

\footnotetext{
65. See text accompanying note 61 supra.

66. See Dep't of Treasury, IRS Form 5300 (rev. June 1976). See also Dep't of Treasury, IRS Instructions for Form 5300 (rev. June 1976).

67. Form 5300, supra note 66.

68. See Form 5300, supra note 66, at questions 15, 23(c), 23(e). See also Instructions for Form 5300, supra note 66, Specific Instruction 15.

69. Of course, such double designation of the Poor Corporation's plan in the hypothetical above so clearly violates the spirit of section 414(b) that it would be extremely unwise for any taxpayer to opt for such a course in practice. If a determination letter were obtained from the IRS on the basis of an incomplete or misleading factual submission, the determination would be of dubious value. While the Service normally will not revoke a determination letter retroactively, the Service would clearly not be so bound where the determination letter was issued on the basis of an incomplete or misleading statement of the taxpayer's facts. See Rev. Proc. 62-31, 1962-2 C.B. 517; $c f$. Rev. Proc. 62-30, 1962-2 C.B. 512 (revocation of tax exemption for entering into a prohibited transaction). See also Steven Brothers Foundation, Inc. v. Commissioner, 324 F.2d 633 (8th Cir. 1963); Cleveland Chiropractic College v. Commissioner, 312 F.2d 203 (8th Cir. 1963); I.R.C. $\$ 7805(b) ; ~ c f$. Automobile Club of Michigan v. Commissioner, 353 U.S. 180 (1957) (retroactive revocation held to be permissible where exemption was originally based on a mistake of law).
} 
up to five years and also expressly permitted the exclusion of part-time employees defined as "employees whose customary employment is for not more than twenty hours im any one week, and employees whose customary employment is for not more than five months im any calendar year." $" 70$ Under the pre-ERISA Code, age conditions were not permitted as statutory exclusions. ERISA redefined the permitted service condition as a period of one year of service $m$ which an employee has 1,000 hours of service. ${ }^{71}$ For the first time, ERISA also provided for a minimum age condition - not to exceed age twenty-five-as a statutory exclusion. ${ }^{72}$ These statutory exclusions are relevant in determining whether the percentage test has been met. ${ }^{73}$

In addition, under prior law, the normal administrative practice at the district level was to exclude all employees in the corporation who did not meet the service condition of the plan under review in determining whether a fair cross section existed. The regulations pronulgated under ERISA now reverse the prior practice. They provide expressly that im determining whether a nondiscriminatory classification exists, employees who do not satisfy the minimum age and service conditions must be taken into account. ${ }^{74}$

The mipact of the regulations, of course, will vary from situation to situation. Surprisingly, however, im a large controlled group the practice of imcluding employees in the ineasurement pool who are excluded from coverage by minimum age and service conditions actually can facilitate denonstration of fair cross section coverage. For example, im the case of the hypothetical controlled group described in Table $B$, suppose that im each of the corporations ten percent of the employees in each compensation bracket were not covered by virtue of the plan's minimum age and service conditions. The following coverage would result with respect to designated Plan I-III when such persons are taken into account as required under the regulations.

70. I.R.C. $\S 401(a)(3)(A)$ (amended 1974).

71. 1.R.C. $\$ \$ 410(\mathrm{a})(1)(\mathrm{A}), 410(\mathrm{a})(3)(\mathrm{A})$.

72. I.R.C. $\$ 410(\mathrm{a})(\mathrm{I})(\mathrm{A})$.

73. I.R.C. $\$ 410(\mathrm{~b})(1)(\mathrm{A})$.

74. Treas. Reg. $\$ 1.410(b)-1(b)(2)(1977)$. 
Table E ${ }^{75}$

\begin{tabular}{|c|c|c|c|c|}
\hline $\begin{array}{l}\text { Annual } \\
\text { Compensation }\end{array}$ & $\begin{array}{c}\text { I } \\
\text { All } \\
\text { Employees }\end{array}$ & $\begin{array}{c}\text { II } \\
\text { Covered by } \\
\text { Plan I-III }\end{array}$ & $\begin{array}{c}\text { III } \\
\text { Excluded from } \\
\text { Plan I-III }\end{array}$ & $\begin{array}{l}\text { IV } \\
\text { Excluded from } \\
\text { All Plans }\end{array}$ \\
\hline More than $\$ 25,000$ & 60 & 36 & 24 & 6 \\
\hline$\$ 20,001$ to $\$ 25,000$ & 60 & 36 & 24 & 6 \\
\hline$\$ 15,001$ to $\$ 20,000$ & 60 & 36 & 24 & 6 \\
\hline$\$ 12,501$ to $\$ 15,000$ & 60 & 18 & 42 & 42 \\
\hline$\$ 10,001$ to $\$ 12,500$ & 60 & 18 & 42 & 42 \\
\hline$\$ 7,501$ to $\$ 10,000$ & 60 & 18 & 42 & 42 \\
\hline$\$ 5,001$ to $\$ 7,500$ & 60 & 18 & 42 & 42 \\
\hline
\end{tabular}

After taking into account the age and service conditions of the plans, the coverage is more favorable for qualification than the data in Table D would refiect. ${ }^{76}$ Most significantly, the comparison of the covered employees (Table E column II) with the employees who are excluded froin all plans (Table E column IV) produces results that are at least, arguably, a fair cross section under the test of Revenue Ruling 70-200. ${ }^{77}$

On the other hand, if the universe under coinparison excludes all persons who do not meet the service and age conditions, the following coverage results.

Table F78

\begin{tabular}{|c|c|c|c|c|}
\hline $\begin{array}{l}\text { Annual } \\
\text { Compensation }\end{array}$ & $\begin{array}{c}\text { I } \\
\text { All } \\
\text { Employees }\end{array}$ & $\begin{array}{c}\text { II } \\
\text { Covered by } \\
\text { Plan I-III }\end{array}$ & $\begin{array}{c}\text { III } \\
\text { Excluded from } \\
\text { Plan I-III }\end{array}$ & $\begin{array}{l}\text { IV } \\
\text { Excluded from } \\
\text { All Plans }\end{array}$ \\
\hline More than $\$ 25,000$ & 54 & 36 & 18 & 0 \\
\hline$\$ 20,001$ to $\$ 25,000$ & 54 & 36 & 18 & 0 \\
\hline$\$ 15,001$ to $\$ 20,000$ & 54 & 36 & 18 & 0 \\
\hline$\$ 12,501$ to $\$ 15,000$ & 54 & 18 & 36 & 36 \\
\hline$\$ 10,001$ to $\$ 12,500$ & 54 & 18 & 36 & 36 \\
\hline$\$ 7,501$ to $\$ 10,000$ & 54 & 18 & 36 & 36 \\
\hline$\$ 5,001$ to $\$ 7,500$ & 54 & 18 & 36 & 36 \\
\hline
\end{tabular}

75. Column II of Table $\mathrm{E}$ is the sum of Columns I and III of Table B, less $10 \%$ in each wage bracket. For example, in the highest bracket there are 20 employees in Column I of Table B, and 20 employees in Column III for a total of 40 employees. Ten percent, or four employees, do not meet the age and service requirements, leaving 36 covered employees reflected in Column II of Table E. Column IV of Table E reflects the number of employees of Rich Corp. A, Rich Corp. B and Cross Section Corp. not covered by virtue of their failure to satisfy the age and service conditions, plus the employees of Poor Corp. not covered by any plan.

76. See text accompanying note 63-69 supra.

77. 1970-1 C.B. 101.

78. Column I of Table F simply eliminates the $10 \%$ of employees not meeting the age and serviee conditions. For example, in the highest bracket, there are 60 total employees (see Table B) of which $10 \%$, or six, do not meet the age and service conditions and are thus eliminated. 
Table $\mathrm{F}$ is less favorable than Table $\mathrm{E}$ for meeting the nondiscrimination requireinent because Table $F$, by eliminating froin the coinparison those not satisfying the service and age conditions, increases the ratio of lower-paid employees to higher-paid employees in the category against which the coverage is to be measured: those excluded from all of the controlled group's plans (column IV).

Regulation section 1.410(b)-1(b)(2) undoubtedly is premised on the belief that, contrary to the above example, the age and service conditions will normally exclude nore employees at the lower salary levels than at the higher levels. While this premise is probably accurate, the required inclusion of persons not meeting the statutory age and service requirements is incorrect as a conceptual matter. Age and service exclusions are neutral factors; the mandatory inclusion of persons who are not covered because they fail to meet the plan's age and service criteria in the saine category with persons who are not covered because they are meinbers of a job classification for which no plan is maimtained simply causes confusion. The regulation incorrectly intrudes into an area that would best have been left to the discretion of the examining agent.

4. Comparability in the Controlled Group. Under pre-ERISA law, two or more plans could not be designated as a single plan for purposes of coverage unless the plan for the lower-paid employees was comparable in contributions or benefits to the plan for the higher-paid employees. $^{79}$ Stated differently, if two plans were to be designated as constituting a single plan for coverage purposes, the employer was required to demonstrate that the resulting combination of plans satisfied the general nondiscrimination requireinents of section 401(a)(4). In general, ERISA carried forward the broad requirement of coinparability with a statutory clarification of a technical question-whether differences in vesting affected the comparability of plans. ${ }^{80}$

A general discussion of the standards of comparability is beyond the scope of this Article. However, comparability should be mentioned briefly as a postscript to the discussion of coverage because it remains

79. Rev. Rul. $66-15,1966-1$ C.B. 83 .

80. In Revenue Ruling 71-503, 1971-2 C.B. 206, the Service took the position that differences in the vesting schedule of otherwise comparable defined contribution plans prevented the plans from being considered comparable. In Revenue Ruling 74-165, 1974-1 C.B. 96, the Service retreated from that position and held that differences in vesting do not preveut a finding of comparability provided the rates of contribution are comparable. This rule is codified in section $401(a)(5)$ of the Code as amended by ERISA. In addition, the Service is granted authority to promulgate regulations pursuant to which differences in rates of vesting would be used as an actuarial adjustment factor in determining the comparability of benefits. I.R.C. $\$ 401$ (a)(5). 
an unexamined issue for nost controlled groups. In many groups, there is little uniformity in the plans of the group, especially where the affiliation occurred after the employee benefit plans had been estabhished. Employee benefit plans often have developed on an individual basis tailored to specific geographic locations and industries. Close scrutiny of the comparability of plans of controlled employers could result in plan disqualifications even though plans are maintained by every nember of the group.

Like the law of coverage, the standards of comparability are only partially developed, and virtually all development was arrested with the enactment of ERISA. The most sensible approach to enforcement of the policies underlying section $414(\mathrm{~b})$ is to emphasize elimination of gaps in plan coverage in the controlled group while permitting greater flexibility on the question of comparability than was reflected in the rulings under prior law. ${ }^{81}$ In any event, the issue of comparability will remain in the background until there is inore substantive elaboration of the coverage requirements.

\section{Single Plan Versus Separate Plans for Controlled GROUP OF EMPLOYERS}

The law prior to the enactment of ERISA made joint adoption of a single qualified plan by members of a controlled group difficult. ${ }^{82}$ As a result, affiliated employers frequently adopted plans with similar, or even identical, benefit provisions, but mamtained the plans as separate entities. Section 414(b) is widely viewed by experts in the employee benefit field as erasing these constraints of prior law, and facilitating the adoption of a simgle plan (sometimes referred to as a multiple employer plan ${ }^{83}$ ) by members of a controlled group. However, the use of section 414(b) to adopt a single plan remains subject to a number of unanswered questions.

\section{A. Definition of a Single Plan.}

The initial inquiry is, of course, into what factors distinguish a single plan mamtained by several employers from separate plans main-

81. See text accompanying notes 21-32 supra.

82. See text accompanying notes 21-34 supra.

83. A single plan maintaimed by several affiliated employers is occasionally referred to in the literature as a "multiple employer plan." See Scharf, Establishing Multiple Employer Plan May Be Solution to Section 414 Problems of Controlled Employers, 3 J. Pension Plan \& Compliance 279 (1977). However, the recent proposed regulations under section 413(c) use the term "multiple einployer plan" to refer to plans mamtained by more than one corporation except for plans inaintained by multiple controlled corporations. See note 39 supra. Accordingly, the term inultipleeinployer plan has not been used herein. 
tained by several employers. The most helpful authority on this question is the recent IRS regulations on transfers of plan assets and liabilities under ERISA. ${ }^{84}$ These regulations, promulgated for the purpose of indicating when a transfer of plan assets and liabilities occurs for purposes of section $414(l)$, mclude the following definition of a "single plan":

A plan is a "single plan" if and only if, on an ongoing basis, all the plan assets are available to pay benefits to employees who are covered by the plan .... A plan will not fail to be a single plan merely because. . . :

(i) the plan has several distinct benefit structures which apply either to the same or different participants,

(ii) The plan has several plan documents,

(iii) Several employers, whether or not affiliated, contribute to the plan, ...

(v) Separate accounting is maintained for purposes of cost allocation but not for purposes of providing benefits under the plan. ${ }^{85}$

On the otller liand, the regulations conclude that separate plans exist when the assets available to satisfy plan liabilities are segregated so that the assets contributed by one employer may not be used to satisfy the plan liabilities with respect to the employees of another employer.

The foregoing regulation is illustrated as follows: if a parent corporation and its wholly owned subsidiary each adopt pension plans providing identical benefits but make contributions to a trust fund established pursuant to a trust agreement that specifies that the portion of the trust fund assets contributed by parent and by subsidiary, respectively, may only be used to pay benefits to each of their respective employees, then the plans would not be considered a single plan, even though identical documents are utilized. However, if a corporation and its subsidiary adopt a plan document that contams different benefit formulas applicable to the employees of the parent and of the subsidiary, but that provides that all assets contributed to the trust fund would be available to defray any benefits provided by either plan, then, according to the Service, the plan would be considered a "single plan."

\section{B. Consequences of a Single Plan.}

The inaintenance of a single plan by members of a controlled group will have a number of tax and practical consequences that the maintenance by the same employers of separate plans for their respec-

84. Treas. Reg. §§ 1.401(a)-12, .414(I)-1 (1979).

85. Treas. Reg. $§ 1.414(\zeta)-1(b)(1)$ (1979). 
tive employees would not have. The most significant consequences are summarized below.

1. Unified Reporting. A single plan will be subject to unified government reporting. Only a single filing, rather than multiple filings, would be required for the initial qualification application and for the various periodic filing requirements. ${ }^{86}$ Where separate plans are inaintained, the general requirement is that a separate filing must be made for each separate plan. ${ }^{87}$

2. Asset Allocations. If a single plan is maintained, no allocation of the assets of the single plan will be required to be inade with respect to each of the participating corporate employers, since all plan assets would be available to pay all plan benefits without regard to the identity of the corporation einploying the participant receiving benefits. In contrast, if several controlled employers adopt separate plans but coinmingle assets for investinent purposes, there must be a separate accounting for the assets of each plan that credits each plan with contributions inade to it and with its allocable share of trust income, and that takes account of benefit payments from each plan. ${ }^{88}$

3. Cost Determinations. It appears that the actuarial cost of a single defined benefit plan will be determined for the entire controlled group and apportioned among the participating corporations, rather than determined separately for each participating corporation. ${ }^{89}$ This approach should inake the cost of preparing the annual actuarial evaluation more econonical. In addition, where actuarial cost is determined on an aggregate basis and apportioned annong the members of the group, the cost for individual members inay differ from the cost that would result if cost were calculated separately for each group.

4. Tax Deduction Rules. Except for the qualifications noted below, ${ }^{90}$ the tax deduction for contributions to the single plan should be determined on an aggregate basis and apportioned among the menbers of the group. In addition, the full fnnding limitation on deductions

86. See U.S. Dep't of Labor, Form EBS-1; Pension Benefit Guaranty Corporation, Form PBGC-1 (rev. July 1978); Dep't of Treasury, IRS, Dep't of Labor, Pension Benefit Guaranty Corporation, Form 5500 (1978).

87. See Instructions, Form 5500, supra note 86.

88. See text accompanying notes $105-20$ infra.

89. See text accompanying notes 121-23 infra.

90. See text accompanying notes 105-20 infra. 
under section 404 would only be applicable in the event of a full funding excess for all plans combined. ${ }^{91}$ In contrast, where the members of the group maintain separate plans, some inembers may be limited as to their deductible amount by the full funding limitation at a time when other plans within the group are subject to substantial actuarial deficiencies.

5. Plan Terminations. If separate plans are maintained for each neinber of the controlled group, the termination of the coverage of one corporation (for example, by virtue of the sale of a subsidiary) results in a plan termination with consequent full vesting of all covered employees, and mandatory proceedings before the Pension Benefit Guaranty Corporation (PBGC). ${ }^{92}$ If the plan is underfunded, a potential deficiency may be assessed by the PBGC against the employer. ${ }^{93}$ In contrast, if a single plan is maintained by the controlled group, the termination of a seginent of employees froin coverage under the plan (for example, by virtue of the sale of a subsidiary) inay not be considered a plan termination for PBGC purposes. ${ }^{94}$

91. Rev. Rul. 64-159, 1964-1 (Part I) C.B. 163. See also I.R.C. § 412(c)(7).

92. ERISA § 4041.

93. ERISA \& 4062(b).

94. A considerable body of law governs the termination of a qualified plan. In general, the law draws a distinction between termination of a qualified plan for federal tax purposes, and termination of the plan for purposes of the insurance coverage of the PBGC.

Termmation of a plan for federal tax purposes raises potential issues pertaining to the plan's qualification. A requirement of tax qualification under section 401 is that a plan be a program sponsored by an employer with the intention that it will be permanent. Treas. Reg. $\S 1.401-1(b)(2)$ (1977). An early abandonment of the plan without valid business reason may indicate that the plan was never intended as a permanent plan, and may therefore cause retroactive disqualification of the plan. Rev. Rul. 69-24, 1969-I C.B. 11 . In addition, if at the time of discontinuance, benefits available for rank-and-file employees are not comparable to the benefits available for highly paid personnel, the IRS may contend that the plan was not maintained for the exclusive benefit of employees. See Rev. Rul. 69-25, 1969-I C.B. 113. Finally, the Code requires that a participant's rights to benefits accrued in a qualified plan must become completely nonforfeitable upon "termination" or "partial termination" of the plan to the extent that the assets held under the plan are sufficient to provide benefits. See I.R.C. \&411(d)(3)(A).

The issue of whether a plan has wholly or partially terminated for tax purposes is one of fact. See Treas. Reg. $§ 1.401-6(b)$ (1977). There is normally no factual question when a plan is completely terminated, but difficult questions occur in the "partial termination" context. Where a group of employees sever employment, the question arises whether this simply constitutes multiple regular terminations under the plan (subject to the regular vesting rules) or whether, on the other hand, a partial termmation of the plan has occurred. The regulations merely provide that this determination will be made based on all the facts and circumstances. Two pre-ER1SA rulings illustrate such factual determinations: Revenue Ruling 72-510, 1972-2 C.B. 223 and Revenue Ruling 73-284, 1973-2 C.B. 139. The thrust of these rulings is that the discontinuance of any significant discrete business segment results in a partial termination for tax purposes.

From the viewpoint of the PBGC, the termination or partial termination of a plan raises 
6. Transfer of Employees Between Corporations. Where separate plans are mamtained by each member of the group, the transfer of einployees between corporations may result in complex consequences. If the group members desire to transfer assets corresponding to the actuarial liability assumed in connection with the einployee transfer froin one plan to another, then the employer must comply with the elaborate rules governing transfers of plan assets and liabilities. ${ }^{95}$ These difficulties are eliminated where a single plan covers both corporate entities simce there is no transfer of assets or liabilities as a result of an employee transfer.

\section{Merger of Separate Plans into a Single Plan.}

The advantages of a single plan over a separate plan for a controlled group of corporations understandably promote a desire to convert the members' various plans imto a simgle one. Frequently, the plans have similar benefit structures, and the assets already are held in a single commingled imvestment trust.

The merger of controlled group plans is governed by section $414(l)$ of the Code..$^{96}$ The purpose of this provision is to insure that a merger

different issues. The critical question is whether an event has occurred that triggers the plan termination insurance provisions of ERISA. See ERISA $\$ \S 4001-4068$.

In general, ERISA provides for insurance to plan participants when assets are insufficient to pay basic benefits under a plan that has been "terminated" either by the plan administrator (ERISA \& 4041) or by the PBGC (ERISA \& 4042). The statutory scheme leaves many unanswered questions about what constitutes termination. The application of the PBGC definition of termination leaves considerable uncertainty in the context of a partial termination in which some of the employees covered by a plan cease employment by virtue of the sale of a division or subsidiary. Section 4043(b)(4) of ERISA expressly states that a partial termination for tax purposes does not by itself constitute or require a termination for PBGC insurance purposes. Some evidence in the legislative history of section 4043 supports the proposition that the insurance provisions are triggered in the event of partial terunination. See materials cited in Gilcrist, (ERISA)-Plan Terminations: Corporate Acquisitions, 312 TAX MANAGEMENT A-38 (1976). Nonetheless, the PBGC itself has taken the position that many partial terminations are not covered exccpt as expressly provided by ERISA. See Letter of PBGC in connection with Anthracite Health and Welfare Fund, Case No. 140-1, Pens. Rep. (BNA) (Aug. 21, 1975) and Pens. Rep. (BNA) R-2 (Aug. 25, 1975).

The evolving standard of the PBGC seems to focus on the reportable event requirement of ERISA $\S 4043(b)(3)$. According to that section, a reportable event occurs when "the number of active participants is less than $80 \%$ of the number of such participants at the begimning of the plan year." Id. In the case of a closing or disposition of a segment of the business covering participants in a plan comprising less than $20 \%$ of the total participants in a larger plan, the PBGC will not necessarily take the position that a termination for PBGC purposes has occured even if there is partial termination for tax purposes.

95. See ERISA § 208;-1.R.C. §§ 212(I), 40I(a)(12); Treas. Reg. § I.414(l)-I(b)(3) (1979).

96. I.R.C. $\S 414(I)$ provides:

Mergers and Consolidations of Plans or Transfers of Plan Assets.-A trust which forms a part of a plan shall not constitute a qualified trust under section 401 and a plan shall be treated as not described in sections 403 (a) or 405 unless in the case of any merger or consolidation of the plan with, or in the case of any transfer of assets or liabilities of such plan to, any other trust plan after September 2, 1974, each participant in the plan would (if the plan then terminated) receive a benefit immediately after the merger, con- 
of plans or a transfer of plan assets and liabilities does not result in diminislied benefit security, as measurcd on a plan termination basis, for any participant. Under regulations promulgated pursuant to section $414(l)$, the term "merger" is defined as any combination of two or more plans into a single plan. ${ }^{97}$

The section $414(l)$ regulations provide that no merger of separate plans will be permitted unless one of two conditions is met. First, a merger of separate plans will be considered to satisfy section $414(l)$ if the merged plan is "fully funded"; that is, if the sum of the assets of all the plans to be merged is not less than the sum of the present value of the accrued benefits of all plans using reasonable actuarial assumptions. ${ }^{98}$ If the merged plan is not fully funded, a "special schedule of benefits" procedure inust be followed. ${ }^{99}$ The special scliedule procedure calls for alteration of the plan's allocation of assets on a future plan termination basis so that participants of the better-funded plan do not lose benefit security as a result of the merger. The calculation of a special scliedule of benefits need not be made if an enrolled actuary certifies that the necessary data will be maintained for five years im order to make such a determmation as of the date of merger. ${ }^{100}$

The regulations governing the division of plans include a grandfather clause that permits defined benefit plans mamtained for different groups of employees under which separate accounting of assets has been maintained to spin off (or divide) into separate plans on or before July 1, 1978, if the liabilities and assets of eacli group of employees were allocated to the group in the division. ${ }^{101}$ No similar grandfather clause is proposed for a merger of plans. Accordingly, plans of controlled employers inay be combined only in situations in which botli plans are fully funded, unless the employer is willing to undergo the expense of the special schedule procedure. ${ }^{102}$

solidation, or transfer which is equal to or greater than the benefit he would have been entitled to receive immediately before the merger, consolidation, or transfer (if the plan had then terminated). This paragraph shall apply in the case of a multiemployer plan only to the extent determined by the Pension Bencfit Guaranty Corporation.

97. Treas. Reg. $\$ 1.414(\zeta)-1(b)(2)$ (1979).

98. Treas. Reg. $\$ 1.414(l)-1(\mathrm{e})(1)(1979)$.

99. Treas. Reg. $\$ 1.414(1)-1(\mathrm{e})(2)$ (1979).

100. Treas. Reg. $\$ 1.414(/)-1(\mathrm{i})(1)(1979)$.

101. Treas. Reg. $\$ 1.414(\zeta)-1(\mathrm{n})(3)(1979)$.

102. Occasionally, it is unclear whether members of the controlled group maintain a single plan or separate plans. Where plan assets are held in a single commingled trust, the trust agreements may be ambiguous on the question of whether the assets of one plan could be used to satisfy the liabilities of another plan. In such cases the plan sponsor presumably should adopt amendatory language clarifying the situation. Depending upon the facts, there may be room for the sponsor to take the position that the plan was always a single plan and thus was not subject to the plan merger requirements. 


\section{Uncertainties Associated with Maintenance of Single Plans in the Controlled Group.}

Since the advantages of a single plan versus several separate plans outweigh the disadvantages in some cases, controlled employers are experimenting with the adoption of single plans and, where possible under the plan merger rules, with the combination of previously separate plans into a single plan. However, assuming a single plan can be adopted for a particular controlled group of corporations, the steps necessary to remain in compliance with ERISA are unclear.

Section 414(b) itself provides that the Service may prescribe regulations governing the application of the minimum funding standards and the apportionment of applicable limitations under section 404(a) among corporations when a single plan is adopted by nore than one member of a controlled group. Otherwise, section 414 contams no limitation on the flexibility of affiliated employers in establishing a single plan for the benefit of their respective employees. The Service has failed thus far to promulgate rules pursuant to its rulemaking power under these sections; indeed, the Service has permitted the relevant preERISA rules to remain on the books despite the philosophical inconsistencies between section 414(b) and those rules. ${ }^{103}$ The next section will exainine the tax consequences ${ }^{104}$ of the allocation of contributions of costs and forfeitures for the simgle controlled-group plan under section 414(b) - as contrasted with their tax consequences under the pre-ERISA "separateness" rules.

1. Profit Sharing Plans: Allocation of Contributions and Forfeitures. In Revenue Ruling $69-35,{ }^{105}$ the IRS considered a profit sharing plan adopted by a parent corporation and its wholly owned subsidiary. The plan provided that contributions to the plan from each corporation would be aggregated and allocated among the accounts of the individual participants in the same proportion that each participant's compensation bore to the total compensation of all participating employees of both corporations. Thus, it was possible that an amount contributed by one corporation might be allocated to employees of another corporation. The Service ruled that the allocation provision did not jeopardize

103. See text accompanying notes 21-30 supra.

104. In extreme situations the maintenance of a "single" plan by multiple employers also could have tax consequences among the employers outside the context of Subchapter D. For example, absent further published authority, practitioners cannot assume that section 482 and the case law pertaining to constructive dividends between brother-sister corporations do not have at least a peripheral applicability. See authorities cited in note 32 supra. See also I.R.C. $\$ 482$; Rev. Rul. 78-83, 1978-1 C.B. 79; Rev. Rul. 69-630, 1969-2 C.B. 122.

105. $1969-1$ C.B. 117. 
the qualified status of the plans, but that amounts contributed by one corporation were not deductible to the extent that they were allocated to employees of the other corporation: ${ }^{106}$ Similarly, the Service in Revenue Ruling $69-570^{107}$ ruled that a profit sharing plan that permitted forfeitures to be reallocated among all employees in the controlled group would not qualify.

In determining the continued vitality of these rules following the enactment of section 414 (b), one must initially distinguish between a profit sharing plan maintained by a parent-subsidiary controlled group that has elected to file a consolidated income tax return and a profit sharing plan maintained by a brother-sister controlled group or other controlled group that is not filing a consolidated return. ${ }^{108}$ In the case of a controlled group filing a consolidated return, both revenue rulings should be revoked in their entirety. In Revenue Ruling 69-35, ${ }^{109}$ the Service concluded that contributions made by one corporation were not deductible if allocated to another corporation in the controlled group since the parent was not "the employer of those benefitimg from the contribution" within the meaning of section 404 of the Code, which grants a deduction only for contributions by an "employer . . . on account of any employee." 110 Section 414(b) expressly provides that for purposes of section 401 , all einployees employed by any member of the controlled group shall be considered as employed by a single employer. The first sentence of section 414(b), however, does not refer to section 404. Nonetheless, a proper construction of section 404 is that amounts are deductible under section 404 for any contributions on behalf of persons who are considered employees for purposes of section $401 .{ }^{111}$

106. $r d$.

107. 1969-1 C.B. 91 .

108. The Code itself distinguishes between parent-subsidiary groups and brother-sister groups with respect to make-up contributions under I.R.C. \$ 404(a)(3)(B). See note 28 supra.

109. 1969-1 C.B. 117.

110. I.R.C. $\$ 404(a)$.

111. Section 404 by its terms does not impose any literal requirement that a deduction is granted under section 404 only in respect of contributions for an employer's own employees. Section 404(a) simply permits deductions for

contributions ... paid by an employer to or under a stock bonus, pension, profit-shar-

ing, or annuity plan ....

(1) ...

(A) ... In the taxable year when paid, if the contributions are paid into a pension trust, and if such taxable year ends within or with a taxable year of the trust for which the trust is exempt under Section 501 (a) . . . .

The rationale of Revenue Ruling 69-35, 1969-1 C.B. 117, for disallowing an employer's contribution otherwise deductible under section 404 when the contributions are allocated to the employees of another employer is not fully articulated, but it is not based on any literal requirement of section 404.

Section $414($ b) specifically provides that for purposes of section 401 the employees of each 
When this construction is given to section 404, section 414(b) provides statutory authority for permitting a member of the controlled group to deduct contributions on behalf of another member of the group. ${ }^{112}$

Assuming that the literal language of sections 401, 404 and 414 would permit a deduction when one corporation makes a contribution to a profit sharing plan on account of an employee of an affiliated employer, the question remains whether the Service would have underlying policy objections to permitting the deduction. If the controlled group files a consolidated return, there is no substantial policy objection to permitting the deduction. Under the consolidated return rules, the entire group normally would compute its consolidated mcome tax liability after taking into account deductions for profit sharing contributions by every corporation in the group. Of course, some special rules in the consolidated return regulations, such as the rules pertaiming to separate return limitation years, ${ }^{113}$ arguably might be subverted by permitting one corporation to obtain a deduction for payments on behalf of another corporation's employees. On the other hand, the underlying policy reason for section 414(b) is furthered when a plan permits proportionate allocation throughout the controlled group of contributions by any member of the group. These policy considerations substantially outweigh any concerns about distortions in mcome within the group. ${ }^{114}$ Thus, Revenue Ruling 69-35 should be revoked at least to the extent that it applies to controlled einployers who file a consoli-

employer in the control group shall be considered as employed by a single employer. Section 404 literally provides that amounts are deductible for contributions to plans that are exempt under section 501 as a result of their qualification under section 401 . Clearly, in order to maintain qualification under section 401 , as modified by section $414(\mathrm{~b})$, plans will frequently be required to cover employees of more than one entity in the controlled group. A reasonable interpretation of the statutory scheme as a whole is that no impediment exists under section 404 to the deduction of amounts allocated to employees of other employers in the controlled group.

112. Contributions for employees of non-affiliated corporations covered under a joint plan appear clearly deductible under I.R.C. $\$ \S 413(\mathrm{~b})$, (c)(2). Analogously, the contibutions for employees of affiliated corporations should be deductible and the Service's position that section 413 (c) is not applicable to controlled employers is doubtful. See note 39 supra.

113. See Treas. Reg. $\$ 1.1502-21$ (c)(1) (1979).

114. The author believes that section 414(b) expresses a fundamental policy judgment to encourage expansion of plan benefits throughout the controlled group without regard to the artificial distinctions between corporate entities. Different persons of reasonable judgment might reach different policy conelusions under the facts. It would be possible to argue, for example, that the underlying policy of section $414(b)$ is not to encourage broader coverage within controlled groups, but merely to define circumstances in which plans of entities within the group will not be accorded qualified status. In other words, section $414(\mathrm{~b})$ could be viewed merely as a negative sanction. If one accepts the affirmative view of section $414(\mathrm{~b})$, its policies will almost inherently conflict with policies of accurate reflection of income. In the balancing of these policy concerns, this author weighs the broader participation by all employees in the group in the plan as being the overriding poliey concern. 
dated return.

When the employers that jointly sponsor the profit sharing plan are brother-sister corporations, the objections of the Service to revocation of Revenue Ruling 69-35 could well be stronger. The Service could argue that permitting contribution by one corporation of announts allocated to the account of employees of a sister corporation has serious intercorporate economic consequences in which the Service has a substantial interest. As noted earlier, ${ }^{115}$ analogous principles of tax law would support an argument that such a payment is subject to reallocation under section 482 and amounts to a constructive dividend to the common shareholders of the corporation making the payment, followed by a correlative contribution to the capital of the other corporation and payment by the other corporation to the profit sharing plan. ${ }^{116}$ The Service might argue that an amount contributed to a profit sharing plan for allocation to employees of a sister corporation is deductible, if at all, only by the sister corporation, and then only if there is evidence of dividend treatment to the common shareholders (who might also be employees covered by the plan and receiving an allocation). Accordingly, the regulations under section 414(b) may ultimately require that profit sharing contributions to joint plans maintained by brother-sister corporations be allocated solely among the employees of the corporation that makes the contribution.

The potential concerns of the Service are more attentuated with reference to the issue of allocation of forfeitures addressed in Revenue Ruling 69-570. ${ }^{117}$ Section 414(b) repudiates by necessary implication the teclunical "exclusive benefit" rationale of Revenue Ruling 69$570 .{ }^{118}$ The reallocation of forfeitures among all employees within the

115. See note 104 supra and authorities cited in note 32 supra.

116. In general, it is the position of the Service that transfers between related corporations without adequate consideration are subject to constructive dividend treatment "whether or not the motive for the transfer was an attempt improperly to allocate income or deductions between the corporations." Rev. Rul. 78-83, 1978-1 C.B. 80. However, some cases have rejected dividend treatinent when there was no evidence of shareholder benefit. IV.B. Rushing, 51 T.C. 888 (1969): Columbian Rope Co., 42 T.C. 800 (1964). Presumably, there would be shareholder benefit where the shareholder is also an employee-participant.

117. 1969-2 C.B. 91 .

118. 1969-2 C.B. 91. The exclusive benefit rationale of Revenue Ruling $69-570$ is premised on the fact that the term "employer" is used in the singular in section 401(a)(2). Accordingly, in Revenue Ruling 69-570, the Service held that the diversion of plan assets contributed by an employer to benefit another employer's employees is a violation of section 401(a)(2). Yet section 414(b) provides that for purposes of section 401, all employees of all corporations that are meinbers of a controlled group of corporations shall be treated as employed by a single employer. If the employees of another corporate member of the control group are treated as being employed by the employer that contributes to the plan, the diversion of plan assets for the benefit of such other employees could no longer be viewed as violating this narrow exclusive benefit interpretation. See 
controlled group presents a much more remote intercorporate economic consequence than the direct allocation of the employer contribution. The termination of an employee is frequently beyond the einployer's control, or, in the case of discharge, unlikely to be motivated by the intercorporate economic effect of the forfeiture reallocation. When a parent-subsidiary controlled group files a consolidated return there seems to be no legitimate policy objection to the allocation of forfeitures among all employees of all the members of the group. Similarly, in the brother-sister context, the sharmg of an employee in an amount forfeited under a qualified plan seems too indirect a benefit to result in a section 482 allocation or im an argument of dividend treatment to common shareholders of the brother-sister corporation. ${ }^{119}$ On the other hand, the policies of section 414(b) are served by such an allocation. ${ }^{120}$ Accordingly, there is no legitimate policy reason why Revenue Ruling 69-570 should not be revoked in its entirety.

2. Defined Benefit Plans: Uncertainties in Allocation of Cost. In Revenue Ruling $69-525,121$ the Service ruled that in the case of a defined benefit pension plan adopted jomtly by affiliated employers, each employer's contributions to the plan and deduction under section 404 must be determimed by the separate computation of actuarial cost with respect to each adopting employer, unless the separate computation of costs is not "feasible." 122 The only example given of a circumstance in which separate computation of costs is not feasible is a plan adopted by two coinpanies that "contmually shift" employees between the two companies. In that situation, the ruling concludes that the companies

the text accompanying note 31 supra and the argument set forth in note 39 supra that section 413(c)(2) also revokes the exclusive benefit requirement.

119. A forfeiture only occurs under a qualified plan upon the termination of an employee prior to the requisite vesting period stated in the plan. Frequently, of course, such forfeitures are beyond the control of the employer since they result from the employee's volitional act of terminating employment. Even where the employee is discharged, loss of the employee's services in most cases is an event of much greater economic and business significance to the employer than the fact of a forfeiture under the plan. Moreover, the allocation of the forfeiture normally is unpredictable at the time the forfeiture oceurs, since such an allocation depends upon the future status of other employees in the plan during the remainder of the year. For all of the foregoing reasons, the reallocation of a forfeiture pursuant to the terms of a preexisting plan normally could not be viewed as an event providing an adequate basis for a section 482 allocation. As contrasted to, for example, a less than fair market value sale of goods or a below market rate of interest loan, the intercorporate economic consequences of the forfeiture reallocation seem too remote.

120. If one views the policy of section $414(\mathrm{~b})$ as encouraging the placing of employees of the controlled group on equal footing in their participation in qualified plan benefits, then that policy is best served when the forfeitures are allocated evenly among the employees of the group. See text accompanying note 37 supra.

121. 1969-2 C.B. 102.

122. Id. 
could determine cost on an aggregate basis and apportion cost between the two companies in proportion to their respective participating payrolls.

The last sentence of section 414(b) provides that "[w]ith respect to a plan adopted by more than one such [controlled] corporation . . . the applicable limitations provided by section 404(a) shall be determined as if all such einployers were a single employer, and allocated to each employer in accordance with regulations prescribed by the Secretary." "123 It seems clear from the literal language of section 414(b) that the applicable limits of section 404(a)(1) and related limits, such as the full funding limit, will be computed on an aggregate basis. However, whether the basic rule of Revenue Ruling 69-525, which requires separate actuarial cost determination (from which the section 404(a)(1) limits derive), will carry over in regulations to be adopted is unclear.

The legitimate concerns of the Service in this area are similar to those concerning profit sharing plans. ${ }^{124}$ The accurate allocation of costs is essential to the determination of the respective tax liabilities of the affiliated employers; moreover, at least in the case of brother-sister corporations, the misallocation of costs could be viewed as a substantial transfer of benefit from one corporation to the other.

One can imagine fact situations in which proper apportionment of cost would be a matter of concern. Consider the brother-sister controlled group consisting of Corporations A and B. Suppose that Corporations $A$ and $B$ adopt a defined benefit plan grantimg full past service credit. Suppose furtlier that Corporation A has a participating payroll of $\$ 100,000$ consisting of ten employees each age twenty-five with one year of service earning $\$ 10,000$ per annum. Corporation B's participating payroll also is $\$ 100,000$, but consists of one employee age sixty-four with forty years service earming $\$ 100,000$ per annum, who also happens to be the primcipal shareholder of both corporations. Any actuarial inethod that does not precisely reflect the cost for Corporation B would have serious intercorporate reallocation potential, not to mention the question of proper apportionment of the section 404(a)(1)(A)(ii) limit. ${ }^{125}$

123. I.R.C. § 414(b).

124. See text accompanying note 116 supra.

125. The foregoing exainple illustrates most vividly the type of situation in which abuse potential is present. Of course, an actuarial determination of plan cost for the aggregated $A B$ plan would reflect the high actuarial cost of the employee of corporation $B$, whose large benefit inust be funded over the one remaining year of service prior to his normal retirement age. On the other hand, the ten lower-paid employees would have a drastically smaller actuarial cost because their benefits would be funded over the forty years remaining to their normal retirement dates. The issue is the manner in which the aggregate cost of the entire plan is apportioned among the sepa- 
On the other hand, the determination of cost is not an exact science; determinations will vary depending upon the actuarial method selected. Within the confines of a single corporate entity, the Service has historically permitted use of various "aggregate" methods of cost determination, which can be viewed as being less exact than "individual" methods wherem an actuarial cost for each individual employee is computed.

As a practical matter, the criticism of Revenue Ruling 69-525 is that it has been interpreted to always require a separate computation of cost for each corporate entity if it is possible to make such a computation-without regard to whether a separate computation is required to apportion cost accurately. For a controlled group with numerous corporate entities, it is necessary for the actuary to compute a cost for each entity separately. The option of making one cost computation using an aggregate method that is reasonable under the circumstances and apportioning cost between entities has not been available in theory. It is hoped that regulations under section 414(b) will, therefore, appropriately modify the rule of Revenue Ruling 69-525.

\section{CONCLUSION}

In summary, the problems raised by section $414(\mathrm{~b})$ call for prompt attention by the Internal Revenue Service. In the area of coverage and discrimmation, the Service must begin the difficult task of delineatimg the standards that it will apply in implementing the policy of section 414(b) in the controlled group context. This would most effectively be accomplished by the publication of revenue rulings similar to Revenue Ruling 70-200 ${ }^{126}$ that set forth the standards to be apphied. Of critical importance is a clear definition of the relevant included and excluded groups for comparison purposes in establishing a nondiscriminatory classification.

In addition, the Service needs to move promptly to promulgate

rate entities. Clearly, a simplistic method such as apportioning cost in proportion to the participating payrolls would result in a distortion of cost. While atypical, the illustration simply is designed to demonstrate the complexity of this type of problem.

Section 404(a)(I)(A)(ii) of the Code establishes one of the three alternative limits on the maximum tax deductible contribution to a pension plan. That Code section provides that the maximum deductible contribution to a pension plan is an amount necessary to amortize the remaining unfunded cost of past and current service credits as a level amount over the remaining future service of each employee. The section establishes a special limit stating that if the remaining unfunded cost with respect to any three individuals is more than $50 \%$ of the remaining unfunded cost of the entire plan, the amount of the unfunded cost attributable to such individuals may not be deducted any faster than over a fivc-year period.

126. 1970-1 C.B. 101 . 
regulations under section 414(b) governing the allocation of cost within the controlled group. As an intermediate step, the Service should announce the revocation of Revenue Rulings 69-35, 69-525 and 69-570.

The plans of controlled groups of einployers are ainong the inost important in the private sector since they typically include the plans of the very largest employers. Controlled employers are entitled to reasonable answers to the questions raised by ERISA. Such answers should give fair weight to the policy of section 414(b), but also should give weight to the need of employers to have practical and clearly defined rules that permit thein to go about the business of providing retirement benefits to their einployees. 
